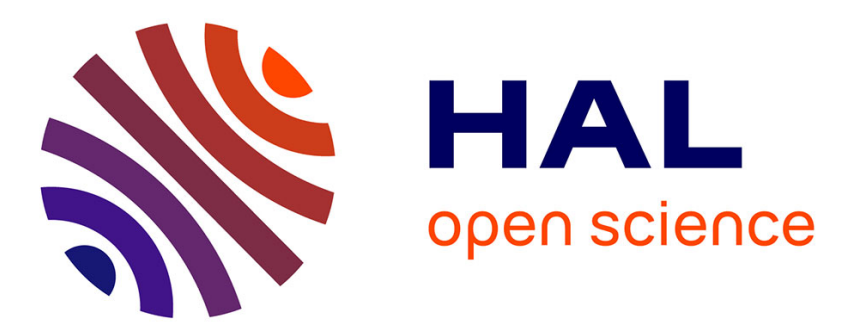

\title{
Preparation of Anode Supported Solid Oxide Fuel Cells (SOFCs) Based on BIT07 and Pr2NiO4+ $\delta$ : Influence of the Presence of GDC Layer
}

\author{
M. Benamira, M. T Caldes, O. Joubert, A. Le Gal La Salle
}

\section{- To cite this version:}

M. Benamira, M. T Caldes, O. Joubert, A. Le Gal La Salle. Preparation of Anode Supported Solid Oxide Fuel Cells (SOFCs) Based on BIT07 and Pr2NiO4+ $\delta$ : Influence of the Presence of GDC Layer. Abdallah Khellaf. Advances in Renewable Hydrogen and Other Sustainable Energy Carriers, Springer Singapore, pp.19-24, 2021, Springer Proceedings in Energy, 10.1007/978-981-15-6595-3_3 . hal03369941

\author{
HAL Id: hal-03369941 \\ https://hal.science/hal-03369941
}

Submitted on 26 Oct 2021

HAL is a multi-disciplinary open access archive for the deposit and dissemination of scientific research documents, whether they are published or not. The documents may come from teaching and research institutions in France or abroad, or from public or private research centers.
L'archive ouverte pluridisciplinaire HAL, est destinée au dépôt et à la diffusion de documents scientifiques de niveau recherche, publiés ou non, émanant des établissements d'enseignement et de recherche français ou étrangers, des laboratoires publics ou privés. 


\title{
Preparation of Anode Supported Solid Oxide Fuel Cells (SOFCs) Based on $\mathrm{BIT07}$ and $\mathrm{Pr}_{2} \mathrm{NiO}_{4+\delta}$ : Influence of the Presence of GDC Layer
}

\author{
M. Benamira ${ }^{1}$ M. T. Caldes ${ }^{2} \cdot$ O. Joubert ${ }^{2} \cdot$ A. Le Gal La Salle ${ }^{2}$ \\ ${ }^{1}$ Laboratory of Materials Interaction and Environment (LIME), University of Mohamed Seddik \\ Benyahia, BP 98 Ouled Aïssa, Jijel, Algeria \\ e-mail:m_benamira@univ-jijel.dz; benamira18@gmail.com \\ ${ }^{2}$ Institut Des Matériaux Jean Rouxel (IMN), Université de Nantes, CNRS, 2, rue de la Houssinière, BP 32229, \\ 44322 Nantes Cedex 3, France
}

\begin{abstract}
In this work, we study the electrochemical performance of anode supported solid oxide fuel cells (SOFCs) based on perovskite-type materials: $\mathrm{BaIn}_{0.3} \mathrm{Ti}_{0.7} \mathrm{O}_{2.85}$ (BIT07) as an electrolyte, BIT07-Ni as a cermet anode and $\operatorname{Pr}_{2} \mathrm{NiO}_{4+\delta}$ as a cathode. Anode/electrolyte assemblies have been prepared by tape casting and co-firing and the cathode has been deposited by screen-printing. The performance of BIT07$\mathrm{Ni} / \mathrm{BIT} 07 / \mathrm{Pr}_{2} \mathrm{NiO}_{4+\delta}$ cells has been determined between 600 and $750{ }^{\circ} \mathrm{C}$ under humidified $\left(3 \% \mathrm{H}_{2} \mathrm{O}\right)$ hydrogen as fuel and air as oxidant. The pres- ence of an interfacial layer of gadolinia doped ceria (GDC) is also tested. Impedance Spectroscopy (EIS) measurements have also been carried out and allowed to differen- tiate between the series and polarization resistances. The power density obtained from the cell with GDC was $119.21 \mathrm{~mW} / \mathrm{cm}^{2}$ at $700{ }^{\circ} \mathrm{C}$, compared with $28.1 \mathrm{~mW} / \mathrm{cm}^{2}$ for the cell without GDC thin layer. These results confirmed that the presence of a dense thin layer of GDC at the interface electrolyte/cathode is a very promising method for intermediate temperature SOFCs (ITSOFCs) to increase the performance.
\end{abstract}

Keywords Tape casting ' SOFC ' EIS ' $\mathrm{Pr}_{2} \mathrm{NiO}_{4+\delta}$

\section{Introduction}

Nowadays, solid oxide fuel cells (SOFCs) operate at 800-1000 ${ }^{\circ} \mathrm{C}$. Reducing the operating temperature of solid oxide fuel cells requires the development of new electrolyte materials with good performance at intermediate temperatures $\left(500-700{ }^{\circ} \mathrm{C}\right)$. $\mathrm{BaIn}_{0.3} \mathrm{Ti}_{0.7} \mathrm{O}_{2.85}$ (BIT07) has the required transport properties and redox stability to be considered as a promising electrolyte material with an ionic conductivity of $10^{-2} \mathrm{~S} \mathrm{~cm}^{-1}$ at $700{ }^{\circ} \mathrm{C}$ and chemical stability under a wide range of partial pressures of oxygen [1-4]. The praseodymium nickelate $\mathrm{Pr}_{2} \mathrm{NiO}_{4+\delta}$ (so-called PNO) is a mixed ionic electronic conducting (MIEC) oxide widely studied as oxygen electrode for solid oxide fuel cells and solid oxide electrolysis cells (SOEC) as well. MIEC oxide attracted particular attention since the oxygen reduction reaction (ORR) has been extended to the whole volume of the electrode, compared to a pure electronically conducting cathode where the ORR is restrained to the triple phase boundary (TPB) points located at the cathode/electrolyte interface [5-9]. 
This paper aims to study the influence of the presence of the material used as an interlayer between the PNO electrode and the BIT07 electrolyte on the electro- chemical performance of the SOFC. $\mathrm{Ce}_{0.8} \mathrm{Gd}_{0.2} \mathrm{O}_{1.9}$ (namely GDC) has been selected as interlayer material. It has also been demonstrated that BIT07 can be used with well- known cathode materials, such as $\mathrm{La}_{0.58} \mathrm{Sr}_{0.4} \mathrm{Co}_{0.2} \mathrm{Fe}_{0.8} \mathrm{O}_{3-}$ ( $\mathrm{LSCF}$ ) or $\mathrm{Nd}_{2} \mathrm{NiO}_{4+} \delta$, and that best results regarding electrochemical performance have been obtained with LSCF.

Our main objective in this work is to prepare a complete Ni-BIT07/BIT07/PNO and Ni-BIT07/BIT07/GDC//PNO cells by tape casting and screen printing. They have been tested under air on the cathode side and wet $\mathrm{H}_{2}\left(3 \% \mathrm{H}_{2} \mathrm{O}\right)$ on the anode side. The performance has been discussed in terms of total resistance determined from current density/voltage curve (J/U) and Electrochemical Impedance Spectroscopy (EIS) measurements at the Open Circuit Voltage (OCV) to understand the origin of this resistance, and to determine the relevant parameters that can be modified in order to minimize it. The stability of the cell presenting the highest performance has been studied at the operating temperature of $700{ }^{\circ} \mathrm{C}$.

\section{Experimental}

$\mathrm{BaIn}_{0.3} \mathrm{Ti}_{0.7} \mathrm{O}_{2.85}$ (BIT07) was synthesised by solid state reaction by using stoichiometric amounts of $\mathrm{BaCO}_{3}$ (Alfa Aesar), $\mathrm{In}_{2} \mathrm{O}_{3}$ (Alfa Aesar) and $\mathrm{TiO}_{2}$ (Merck). Reac- tants were thoroughly mixed using acetone in an agate mortar and calcined at $1200{ }^{\circ} \mathrm{C}$ for $24 \mathrm{~h}$. The obtained powder was again ground well, mixed, pressed into disks and sintered at $1350{ }^{\circ} \mathrm{C}$ for $24 \mathrm{~h}$, ground and passed through mesh $100 . \mathrm{Pr}_{2} \mathrm{NiO}_{4+\delta}$ powder was provided by Marion Technologie and $\mathrm{NiO}$ powder (grain size $0.5-1 \mu \mathrm{m}$ ) was provided by Pharmacie Centrale de France. X-ray diffraction (XRD) was used to characterize the structure of the as-prepared powders. The patterns were obtained using a Brüker "D8 Advance" powder diffractometer with a $\mathrm{Cu} \mathrm{K \alpha}$ radiation $(\lambda=1.54056 \AA)$ and $2 \theta$ varying from 20 to $80^{\circ}$ by steps increments of $0.0146^{\circ}$ and $0.2 \mathrm{~s}$ counting time per step. The Scanning Electron Microscopy (SEM) was performed on a FEG-SEM JEOL 7600. By BrunauerEmmett-Teller (BET), the surface areas of the powders were measured and carried out on a Micromeritics 3Flex analyzer determined by $\mathrm{N}_{2}$ adsorption-desorption isotherm measurement at $-196^{\circ} \mathrm{C}$.

Before cell fabrication and in order to decrease the grain sizes, the as-prepared powders of BIT07 were ball-milled at $500 \mathrm{rpm}$ : $60 \mathrm{~h}$. The anode composition has been
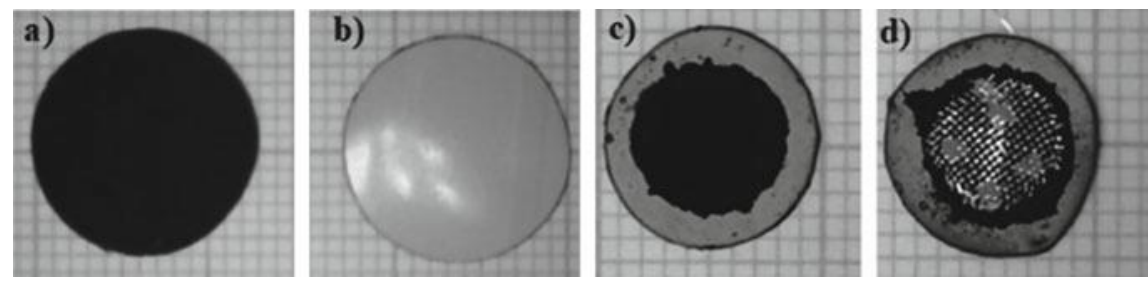

Fig. 3.1 Preparation of Ni-BIT07/BIT07/PNO anode supported cell. a Anode of BIT07-NiO, b electrolyte BIT07, c deposition of PNO cathode, $\mathbf{d}$ current collector of gold grid

optimized to reach the best electrochemical performance, obtained with a BIT07- Ni cermet (BIT07:NiO 50:50 wt\%), realized with a BIT07 powder ball-milled and $5 \mathrm{wt} \%$ $\mathrm{CB}$ as pore forming agent. The button cell $(\varnothing 10 \mathrm{~mm})$ is composed of an anode 
supported electrolyte/anode half-cell, prepared by tape casting and co-fired. Then a PNO cathode is deposited on the electrolyte by screen-printing (Fig. 3.1).

Current collectors, made of discs $(5 \mathrm{~mm}$ in diameter) of gold grid (Goodfellow, wire diameter: $60 \mu \mathrm{m}$ ) are attached on both the electrodes using gold ink. The cell is placed at $120{ }^{\circ} \mathrm{C}$ for overnight to evaporate the solvents and to obtain good electrical contacts. The current-voltage characteristic is measured with the use of a laboratory- made testing system. The cell was sealed on the top of an alumina sample tube. Thus separating the atmospheres between the inside and outside of the tube. The fuel-gas supply tube is situated inside the sample tube. The system was kept vertically in a tubular furnace. The measurements of current density $(\mathrm{J})$ and voltage $(\mathrm{U})$ were done by digital multimeters Keithley 197 and Protek 506, respectively. Current drawn in the circuit was varied using a rheostat. Prior to the measurements, nickel oxide is reduced in situ at $700{ }^{\circ} \mathrm{C}$ for $2 \mathrm{~h}$ under wet $\mathrm{H}_{2}$ and measurements were made at $700{ }^{\circ} \mathrm{C}$, under wet $\left(3 \% \mathrm{H}_{2} \mathrm{O}\right) \mathrm{H}_{2}$ on the anode side, and air on the cathode side.

Electrochemical performances of single cells were studied by electrochemical impedance spectroscopy (EIS). The measurements were realized using a frequency response analyzer Solartron 1260. The impedance spectra were recorded over a frequency range $2 \mathrm{MHz}$ to $0.01 \mathrm{~Hz}$ with a signal amplitude of $10 \mathrm{mV}$ and with 10 points per decade under open circuit conditions from 500 to $700{ }^{\circ} \mathrm{C}$. The EIS diagrams were normalized to the electrode area and fitted using equivalent circuits with the ZView ${ }^{\circledR}$ software (Scribner Associates). Post mortem (after measurements) analyses of the cells have been carried out by SEM, using a JEOL 7600.
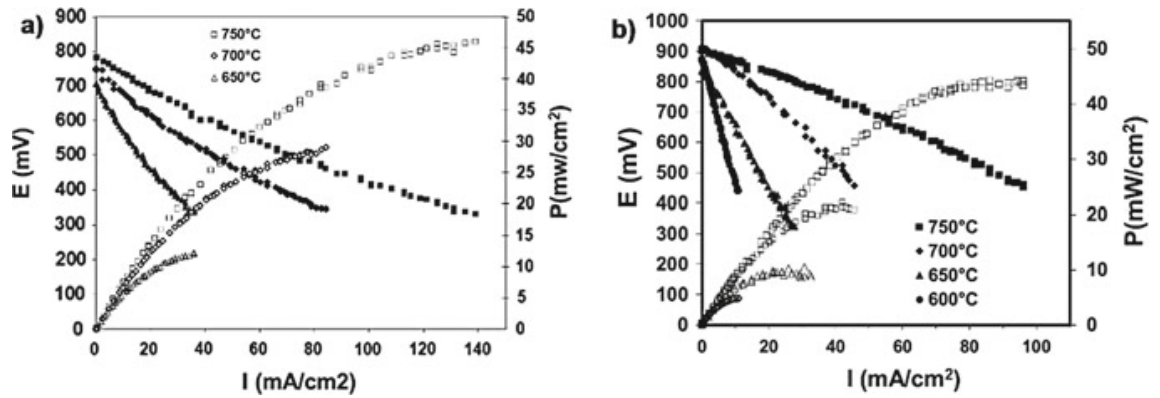

Fig. 3.2 Performance of a single cell consisting in: a Ni-BIT07/BIT07 and $\mathrm{Pr}_{2} \mathrm{NiO}_{4+\delta}$ sintered at 1050 ${ }^{\circ} \mathrm{C}$, b Ni-BIT07/BIT07 and $\mathrm{Pr}_{2} \mathrm{NiO}_{4+\delta}$ sintered at $1100{ }^{\circ} \mathrm{C}$ as the cathode; I-V curves and resulting power densities

\section{Results and Discussion}

\section{Characterization of Material}

Figure 3.2 presents the voltage (U) and power density $(\mathrm{P})$ versus current density

(J) characteristics obtained for two single cells at different temperatures 1050 and 1100 ${ }^{\circ} \mathrm{C}$, respectively, Fig. 3.2a, b. In both cases, the polarisation curves (U/J) are clearly linear in the studied current density range. In both cases, the OCV is lower than the theoretical value expected, suggesting a small leakage between gas chambers. Table 3.1 gathers the cells characteristics obtained from the voltage and power density versus current 
density characteristics and also from the Nyquist diagrams of the single cells.

The extrapolated maximum power densities are of about 28.1 and $22.06 \mathrm{~mW} \mathrm{~cm}^{-2}$ for the two cells, respectively. The ASR value obtained from the EIS measurements, 10.41 for cells $\mathrm{A}$ at $700{ }^{\circ} \mathrm{C}$, is in agreement with the ones obtained from the U/J

Table 3.1 Characteristics of the cell Ni-BIT07/BIT07 and $\operatorname{Pr}_{2} \mathrm{NiO}_{4+\delta}$ sintered at $1050{ }^{\circ} \mathrm{C}$ recorded at $\mathrm{OCV}, \operatorname{ASR}(\mathrm{U} / \mathrm{J})$ calculated from $\mathrm{U} / \mathrm{J}$ curves, ASR(EIS), Rs and $\mathrm{Rp}$ obtained from the EIS measurements

\begin{tabular}{l|l|l|l|l|l|l}
\hline $\mathrm{T}\left({ }^{\circ} \mathrm{C}\right)$ & $\begin{array}{l}\mathrm{OCV} \\
(\mathrm{V})\end{array}$ & $\mathrm{P}_{\max }\left(\mathrm{mW} \mathrm{cm}^{-2}\right)$ & $\mathrm{ASR}_{(\mathrm{U}-\mathrm{J})}\left(\mathrm{Qcm}^{2}\right)$ & $\begin{array}{l}\left.\mathrm{ASR}_{(\mathrm{Nyquist}}\right) \\
\left(Q \mathrm{~cm}^{2}\right)\end{array}$ & $\begin{array}{l}\mathrm{Re} . \mathrm{S} \\
\left(Q \mathrm{~cm}^{2}\right)\end{array}$ & $\begin{array}{l}\mathrm{Rp} . \mathrm{S} \\
\left(\mathrm{Qcm}^{2}\right)\end{array}$ \\
\hline 600 & 0.875 & 4.83 & 41.34 & 43.39 & $\begin{array}{l}3.46 \\
(7.4 \%)\end{array}$ & $\begin{array}{l}39.93 \\
(92.6 \%)\end{array}$ \\
\hline 650 & 0.843 & 9.85 & 18.81 & 20.27 & $\begin{array}{l}2.20 \\
(9.8 \%)\end{array}$ & $\begin{array}{l}18.07 \\
(90.2 \%)\end{array}$ \\
\hline 700 & 0.914 & 22.06 & 9.75 & 10.41 & $\begin{array}{l}1.01 \\
(8.8 \%)\end{array}$ & $\begin{array}{l}9.40 \\
(91.2 \%)\end{array}$ \\
\hline 750 & 0.900 & 44.13 & 4.64 & 5.63 & $\begin{array}{l}1.14 \\
(16.8 \%)\end{array}$ & $\begin{array}{l}4.49 \\
(83.2 \%)\end{array}$ \\
\hline
\end{tabular}

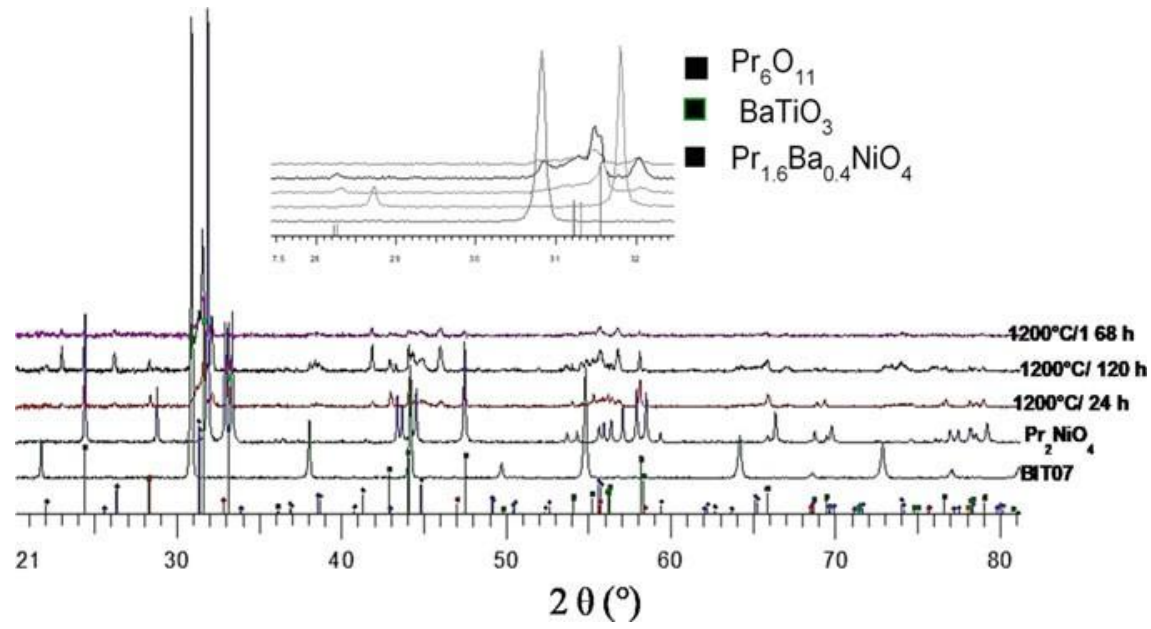

Fig. 3.3 X-ray diffraction patterns of $\mathrm{BIT} 07 / \mathrm{Pr}_{2} \mathrm{NiO}_{4+\delta}$ composite pellets that were calcined at 1100 ${ }^{\circ} \mathrm{C}$ for different times

curves, 9.95. Those values are too high with a major contribution of polarization resistance $(91.2 \%)$ and need more improvement. Thus indicates that the polarization resistance played an important role in cell performance.

In order to understand the origin of the low performances of the two cells, the reac- tivity test between BIT07 and $\mathrm{Pr}_{2} \mathrm{NiO}_{4+\delta}$ powders for more than $168 \mathrm{~h}$ at $1100{ }^{\circ} \mathrm{C}$ was done as shown in Fig. 3.3. Indeed, the DRX analysis reveals the significant pres- ence of a new phase $\left(\mathrm{Pr}_{1,6} \mathrm{Ba}_{0,4} \mathrm{NiO}_{4}\right)$ due to the reaction between the electrolyte and cathode. Considering the reactivity of the $\operatorname{Pr}_{2} \mathrm{NiO}_{4+\delta}$ with BIT07, the higher power densities would expect to be achieved by using a thin interfacial layer of GDC.

A thin interfacial layer $(5 \mu \mathrm{m})$ of GDC is deposited to the electrolyte/anode half- 
cell by screen-printing and co-fired at $1350{ }^{\circ} \mathrm{C}$ for $8 \mathrm{~h}$. Then a PNO cathode is deposited on the electrolyte by screen-printing. To demonstrate the benefit of incorporating a thin layer at the interface between the electrode and electrolyte, the I-V-P curves of the fuel cell are shown in Fig. 3.4. The power density obtained from the cell with GDC thin film was about $119.21 \mathrm{~mW} / \mathrm{cm}^{2}$ at $700{ }^{\circ} \mathrm{C}$, compared with about 28.1 $\mathrm{mW} / \mathrm{cm}^{2}$ for the cell without thin film.

\section{Conclusion}

In this work, anode supported cells based on BIT07 as an electrolyte, BIT07-Ni as anode and $\mathrm{Pr}_{2} \mathrm{NiO}_{4+\delta}$ as cathode have been successfully realized by tape casting and screenprinting. The reactivity test between BIT07 and $\mathrm{Pr}_{2} \mathrm{NiO}_{4+\delta}$ powders reveals the presence of a new phase $\left(\operatorname{Pr}_{1,6} \mathrm{Ba}_{0,4} \mathrm{NiO}_{4}\right)$ which explain the low performances of the single cell. The power density of a single cell with GDC thin film at the interface electrolyte/cathode
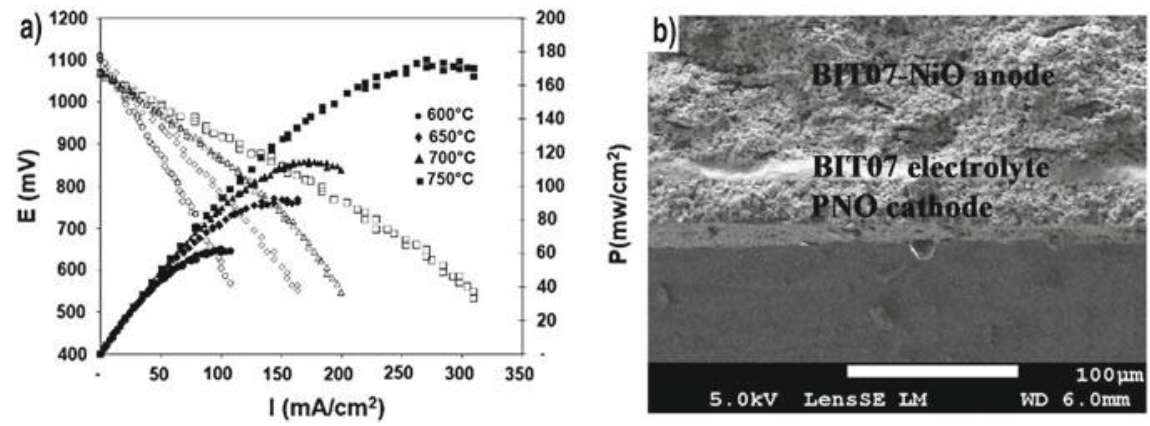

Fig. 3.4 a Performance of a single cell consisting in Ni-BIT07/BIT07/GDC/Pr $2 \mathrm{NiO}_{4+\delta} ; \mathrm{I}-\mathrm{V}$ curves and resulting power densities, $\mathbf{b}$ scanning electron microscope image (cross-section) of single cell

was significantly higher than that of a single cell without interfacial layer. This is attributed to increased interfacial area. The factors such as the better electrocatalytic activity of ceria and the intrinsic properties of nanostructured thin films.

\section{References}

1. F. Moser, M.T. Caldes, M. Benamira, J.M. Greneche, P. Leone, O. Joubert: Development of new anodes compatible with the solid oxide fuel cell electrolyte $\mathrm{BaIn}_{0.3} \mathrm{Ti}_{0.7} \mathrm{O}_{2 \cdot 85}$. J. Power Sour 201, 103-111 (2012)

2. M. Benamira, M. Letilly, E. Quarez, O. Joubert, A.L.G. La Salle, Optimization of SOFC anode/electrolyte assembly based on $\mathrm{BaIn}_{0.3} \mathrm{Ti}_{0.7} \mathrm{O}_{2.85}$ (BIT07)/Ni-BIT07 using an interfacial anodic layer. J. Power Sour. 251, 66-74 (2014)

3. M. Benamira, L. Thommy, F. Moser, O. Joubert, M.T. Caldes, New anode materials for IT- SOFC derived from the electrolyte BaIn0.3Ti0.7O2.85 by lanthanum and manganese doping. Solid State Ionics 265, 38-45 (2014)

4. M. Letilly, A. Le Gal La Salle, M. Caldes, M. Marrony, O. Joubert, Validation of 
BaIn $0.3 \mathrm{Ti}_{0.7} \mathrm{O}_{2.85}$ as SOFC electrolyte with Nd2NiO4, LSM and LSCF as cathodes. Fuel Cells 9, 622-629 (2009)

5. E. Lay, M. Benamira, C. Pirovano, G. Gauthier, L. Dessemond, Effect of Ce-doping on the electrical and electrocatalytical behavior of $\mathrm{La} / \mathrm{Sr}$ chromo-manganite perovskite as new SOFC anode. Fuel Cells 12, 265-274 (2012)

6. M. Benamira, A. Ringuedé, M. Cassir, D. Horwat, P. Lenormand, F. Ansart, J.P. Viri- celle, Enhancing oxygen reduction reaction of $\mathrm{YSZ} / \mathrm{La}_{2} \mathrm{NiO}_{4+\delta}$ using an ultrathin $\mathrm{La}_{2} \mathrm{NiO}_{4+\delta}$ interfacial layer. J. Alloy. Compd. 746, 413-420 (2018)

7. M.T. Caldes, K.V. Kravchyk, M. Benamira, N. Besnard, O. Joubert, O. Bohnke, N. Dupré, Metallic nanoparticles and proton conductivity: improving proton conductivity of $\mathrm{BaCe}_{0.9} \mathrm{Y}_{0.1} \mathrm{O}_{3-\delta}$ and $\mathrm{La}_{0.75} \mathrm{Sr}_{0.25} \mathrm{Cr}_{0.5} \mathrm{Mn}_{0.5} \mathrm{O}_{3-\delta}$ by Ni-doping. ECS Trans 45, 143-154 (2012)

8. J.M. Bassat, M. Burriel, O. Wahyudi, R. Castaing, M. Ceretti, P. Veber, J.A. Kilner, Anisotropic oxygen diffusion properties in $\mathrm{Pr}_{2} \mathrm{NiO}_{4+\delta}$ and $\mathrm{Nd} 2 \mathrm{NiO} 4+\delta$ single crystals. J. Phys. Chem. C 117, 26466-26472 (2013)

9. C. Allançon, A. Gonthier-Vassal, J.M. Bascat, J.P. Loup, P. Odier, Influence of oxygen on structural transitions in $\mathrm{Pr}_{2} \mathrm{NiO}_{4+\delta}$. Solid State Ionics 74, 239-248 (1994) 